\title{
Development of Pemswalinal Teamwork Model for Education Staff in State Aliyah Madrasah 2 Model Padangsidimpuan
}

\author{
Erwin Kelana Nasution \\ Postgraduate Education Management, State University of \\ Medan, Medan, 20221 North Sumatera Indonesia \\ email: erwinkelana5@gmail.com
}

\author{
Busmin Gurning \\ Postgraduate of Language and art Education State \\ of Medan, 20221 North Sumatera Indonesia \\ email: busmingurning@gmail.com
}

\author{
Rosmala Dewi \\ Postgraduate of counceling guidance Education, State University \\ Of Medan, Medan, 20221 North Sumatera Indonesia \\ Email: ros_dw@gmail.com
}

\begin{abstract}
The Objective of the research is to: Find the model of pemswalinal teamwork in educational staff at public Madrasah Aliyah Negeri 2 Model Padangsidimpuan; piloting a guide for the pemswalinal teamwork model; produce an implementation guideline of the effective the teamwork pemswalinal model in education staff in MAN 2 Model Padangsidimpuan. Meanwhile the method used in this research is Research and Development $(R$ $\&$ D) by following the steps of research \& development and process of stage in building research products. This research was conducted in public Madrasah Aliyah 2 Model Padangsidimpuan, subject in this study are: head of madrasah, teacher and employes while the object is documents, among other, the result of meeting, regulations, vision and mission of the madrasah, data of the name of teachers and employess as well as documents about the teachers duties and employes and data on fasilities. To find out the effectiveness of the use of pemswalinal teamwork model, the researcher used quessionnaires and forum group discussion (FGD) as well as interviews with stakeholders, as well as madrasah management comittes in public madrasah aliyah 2 of model padangsidimpuan. The results showed that the quality of education increased after applying the development of pemswalinal teamwork model to before the existence of pemswalinal teamwork model. Based on the results of the research, head of regional office of the ministry of religion affairs of nort sumatra province is expected to implement pemswalinal teamwork model to all Madrasah Aliyah in improving the quality of education in their respective institution
\end{abstract}

Keyword: Development pemswalinal teamwork model, Madrasah, Education staff.

\section{INTRODUCTION}

The madrasah-based management component consists of the management of curriculum and teaching programs, management of education personnel, student management, financial management and financing, facilities and infrastructure management, management of madrasah relations with the community, and seven special service management. This is controlled by education personnel led by madrasah heads. Therefore, the management of education personnel is needed.

The head of the madrasah is assisted by several expert staff consisting of teachers and employees called teamwork to carry out the tasks of management of the education staff. Teamwork members will complement each other for the realization of what they aspire to.

One of the superior and full of madrassas that can be used as a reference for formulating a madrasah-based management in North Sumatra is Padangsidimpuan Model 2 State Madrasah Aliyah. In the beginning, this madrasah did not apply teamwork in carrying out tasks. After the formation of teamwork to help madrasah leaders, many progress can be achieved and tasks can be carried out. He is able to formulate and implement policies relating to the management of education personnel. The teamwork model applied in the State Aliyah Madrasah 2 Padangsidimpuan model is the Pemswalinal team model.

Against the background of the above, the researcher was interested in conducting research in the State Aliyah Madrasah 2 Model Padangsidimpuan with the title "Development of Pemswalinal Teamwork Model for Education Personnel in State Aliyah Madrasah 2 Model Padangsidimpuan. The problem of this research is how is the Teamwork Pemswalinal model on education staff in State Aliyah Madrasah 2 Model Padangsidimpuan ? What is the result of the trial of the teamwork Pemswalinal model on the education staff at State Aliyah Madrasah 2 Model Padangsidimpuan? What influences of implementation of teamwork Pemswalinal State Aliyah Madrasah Model 2 Padangsidimpuan?

\section{TEAMWORK MODEL OF EDUCATION STAFF IN} ALIYAH MADRASAH

\section{A. Teamwork Concept Education Staff at Madrasah Aliyah}

Teamwork is a group of people who have expertise and have different information or data in collaboration to achieve a common goal. Newstorm explains "A task team is a cooperative small group in regular contact that is engaged in coordinating action. When the member of a task team knows their objectives, contributes responsibly and thusiastically to the task, and supports one another, they are exchibiting teamwork" [1]. Slocum and Hellriegel also 
explained"teamwork is what they hold themselves mutually accountable" [2].

In an education unit there are teachers, staff, students and infrastructure. All of these elements are related to one another. As one form of education unit, madrasah heads also lead teachers and employees who have different skills and have different information and data, but they have the same goal, which is to realize students who behave nobly and have skills in life that are poured out in the vision and mission of the madrasa. $\quad h$. . The purpose of a madrasah will not be achieved without teamwork members' cooperation and communication. Slocum and Hellriegel explained:

The key point is that such goals cannot be achieved without the cooperation and communication of team members. When a team is formed, its members must have or quickly develop the right mix of competencies to achieve the team's goals. Also it members need to be able to influence how they will work together to accomplish those goals [3].

The madrasah head must be able to form teamwork that will help him to carry out joint tasks in order to realize the national education goals, the vision and mission of the ministry of religion and the madrasa. All competencies and expertise that vary in a madrasah must be collected for a common goal so that each element contributes to realizing the common goal. It is a set of skills used to encourage mutual success. Teamwork education personnel are not limited to madrasah leaders. Therefore members of the education teamwork team can get experience from other teamwork members. Fellow members of the education teamwork will complement each other to achieve these common goals.

Thus it can be concluded that the teamwork of madrasah education personnel is a collection of a number of educational staff in a madrasah education unit, be it teachers or other education personnel who each have skills, information and data that complement each other to achieve common goals contained in the vision and mission, the madrasah education unit, the ministry of religion and national education goals. The concep of education teamwork can be described as follows:

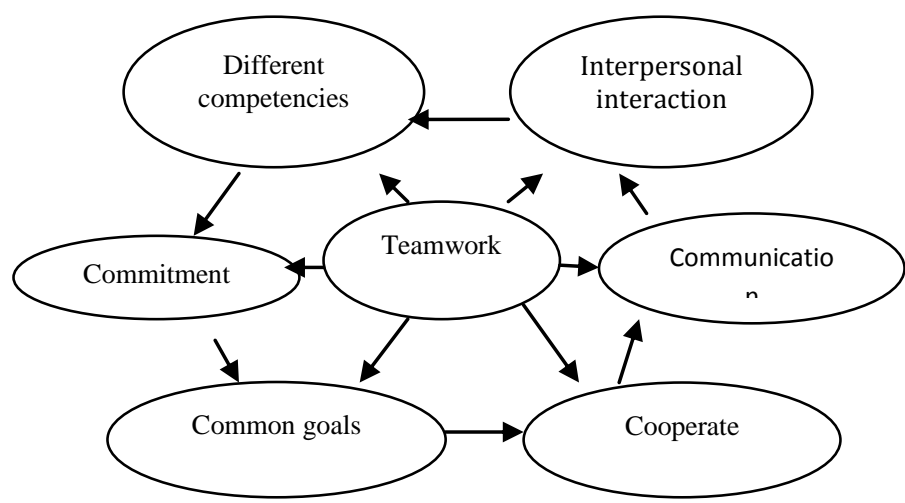

Fig 1.Characteristics of Teamwork Education Staff

West explained that there are several indicators of cooperation, namely: The responsibility of jointly completing the work, namely by giving responsibility can create good cooperation, contribute to each other by contributing both energy and mind to the creation of cooperation, maximizing knowledge that is, by maximizing the ability of each team member to the maximum, the collaboration will be stronger and quality [4]. Marwel also said that high-performance teamwork collaboration is characterized by high reciprocity trust among its members, meaning members believe in the integrity, character and ability of each member [5] Arends also expressed his opinion about the teamwork indicators including: Interpendency, namely the involvement of the entire team in working on shared tasks where each group member is dependent on one another,sharing skills, participation / contribution skills, communication skills [6].

Teamwork educational staff in a madarasah has six characteristics as a concept, namely: competence, commitment, shared goals, collaboration, interpersonal interaction and communication. An educational staff teamwork must also have these six characteristics.

\section{Competence}

Competence is a collection of interrelated knowledge, skills and abilities that a person needs to be effective. This was explained by Slocum and Hellriegel as follows: "A competency is an interrelated cluster of knowledge, skills, and abilities needed by individuals to be effective. A number of competencies can be identified as an support for the effectiveness of most organizations" [7]. When linked to a madrasah-based management environment, staffing can be categorized into two competencies, namely teacher competency and employee competence. Besides the competence of teachers and employees, in a madrasa there are also certain fields that have certain authorities. These authorities are in order to help madrasah heads carry out their duties. The people who are given the authority have certain competencies in accordance with their respective fields, such as the deputy head of the madrasah curriculum field, the deputy head of the madrasah in student affairs, the deputy head of the madrasah in the field of facilities and infrastructure, and certain task fields. In simple terms it can be concluded that all organs in a madrasah-based management organization must be represented in a teamwork. Education staff.

\section{Commitment}

Commitment between members to achieve common goals is one of the characteristics of teamwork. Renee Wingo as Chief People Officer at Virgin Mobile USA stated as follows:"The power of any group or team of people is the power of the mix. you may do all right, but you are not going to create any kind of person who is not a mini version of you."

The initial commitment must be in the madrasah leader. The commitment of the madrasah head to change will influence the teamwork members' commitment. Moorhead and Griffin explained: For teams to succeed, the change must start with top management, who must decide why the change is needed [8].

\section{Common performance goals}

A teamwork must have a common goal. Slocum and Hellriegel explained that team goals are the outcomes desired for the team as a whole, not just goals of individual members. The goal with members of the teamwork in the management of education personnel in a madrasah cannot be separated from the objectives of national education, the vision and mission of the ministry of religion, and the vision and mission of the madrasas concerned [9] .

\section{Working together}

The joint goal of a teamwork will not be achieved if all teamwork members do not work well. Each teamwork member must contribute to achieving the common goal. Slocum and Hellriegel, A universally agreed upon framework of team roles does not exist. For our purposes, member roles in teams can be classified as to whether they are task-oriented, relations-oriented, or self-oriented roles. Each of these roles is over time. This classification underlies most other models of team member roles. Thus, a universally approved teamwork framework does not exist. The role of members in the team can be classified as whether they are task-oriented, relationshiporiented, or self-oriented roles. Each member has the potential to do 
each of these roles from time to time. This classification underlies most other team member role models [[10]

\section{Interpersonal interaction}

Differences in competencies in a teamwork are not to hinder work. Each works according to their expertise and authority. Because each teamwork member has different competencies but has a shared commitment to achieve a common goal by collaborating then they will be sure to interact with each other interpersonally. Each teamwork member must be able to do interpersonal interaction between teamwork members. to communicate things that are important to solve problems and formulate common goals.

\section{Communication}

When interpersonal interactions occur between teamwork members, communication can occur. Therefore, each teamwork member who has different competencies with commitment and goals and cooperation so as to realize interpersonal and communication interactions. Therefore, in a teamwork must be able to communicate effectively and efficiently. Therefore, the elements that exist in communication are communicators, communicants, messages and communication media that greatly influence the communication of teamwork members in a madrasah.

7. The Expired Teamwork Model on Employment Personnel

The forms of teamwork in martial arts in a madrasah vary, according to needs and circumstances. In this paper, the researcher explains the teamwork Pemal-Peminal model in education personnel. Pemswalinal teamwork model consists of four, namely problem solving (Pem), Self-Management (Swakelola), Functional Cross (Lin) and Virtual (al).

a. Problem solving (Pem)

One type of teamwork is problem solving. Teamwork is tasked with solving certain problems in madrasas, such as teamwork to overcome stubborn students, teamwork for sudden facility procurement, teamwork to deal with problematic teachers or employees, teamwork to solve madrasah relationship problems with parents or the community around madrasas and so forth This teamwork is very important to be formed to solve certain problems that exist in madrasas.

The problem solving team is a temporary team formed to attack certain problems at work. The team can use a number of methods to solve problems. After solving the problem, the team is usually disbanded, allowing members to return to their normal work. The Madrasah Head can form teamwork to solve this problem to help him find problems and solve problems that exist in a madrasah. The madrasah head must be able to form effective teamwork to solve this problem. Slocum and Hellriegel explained;"To make teams more effective, managers must know how to recognize effective and ineffective teams. An effective team or group has the following core characteristics. It members 1) know why they have shared goals, 2) support agreed upon guidelines for making decisions, 3) communicate freely among themselves 4) Receive help from one another and give help to one another 5) Deal with conflict openly and constructvely; 6) Diagnose its own process and improve their own functioning; [11]. b. Self-management (Self)

Basically, self-management is the implementation of work that is planned, done and supervised by itself. Self-managed teamwork is the same as how madrasah management does its own teamwork management. In management science, this term is better known as team management.

Management teams consist of managers from various areas and coordinate work teams. They are relatively permanent because their work does not end with the completion of a particular project or the resolution of a problem. Management teams must concentrate on the teams that have the most impact on overall corporate performance. The primary job management teams are to coach and counsel other teams to be self-managing by making decisions within the team. The second most important task of management teams is to coordinate work between work teams that are interdependent in some manner.

c. Functional Cross (Lin)

Functional crossing means that a teamwork has cross-functional members. Each member has their own expertise to carry out certain tasks. One form of educational staff teamwork in a madrasah is a collection of several education personnel to solve certain problems. This model in management science is better known as the work team type. Moorhead and Griffin explained the following :Work teams tend to permanent, like QCs, but they are teams that do the daily work, rather than the auxiliary committee [12].

This Work Team or cross functional in a madrasah is usually to carry out certain tasks that require different skills to complete certain tasks that require a variety of skills or competencies. For example, teamwork is responsible for planning activities and budgets every year, teamwork is tasked with developing the quality of teachers and employees, teamwork that is responsible for selecting students, teamwork tasked with carrying out certain projects, such as the procurement of textbooks, the construction of study rooms or other facilities, etc..

d. Virtual (Al)

Teamwork members should always conduct studies for the development of tasks and products from the teamwork. Only, teamwork members cannot always be present at the same place and time. Therefore, they need technology facilities that can carry out meetings or studies continuously despite different distances and times. One way is to use communication media. Teamwork that utilizes communication media to study or discuss existing teamwork is called Virtual teams. Moorhead and Griffin explained that Virtual teams are as follows:Virtual teams are a team that never actually meets together in their same room-taking activities on the computer via teleconferencing and other electronic information systems.

\section{RESEARCH METHODOLOGY}

This research includes educational research in the field of management using qualitative methods. Burhan Bungin explained that qualitative research aims to describe, summarize various conditions, situations, or variables that arise in society that become an object of research, then draw to the surface as a feature or description of certain conditions, situations or variables [13]. The researcher tried his best to describe, summarize the various conditions and situations related to the development of the National Teamwork model in the education staff atState Aliyah Madrasah 2 Model Padangsidimpuan ..

This research was carried out about one year at Padangsidimpuan Model 2 Public Elementary School Madrasah Sutan Soripada Mulia No. 25 Padangsidimpuan North Sumatra. The subjects in this study were the heads of madrasas, teachers and their employees. The focus of this research is the development of a teamwork Pemal-Pemal model on education personnel.

The method used to answer the problem problem in this study is to use the Research and Development (R \& D) method, where the researcher will take ten steps systematically, namely:

1. Preliminary Study;

2. Literature Study for model development;

3. Design Development;

4. Preliminary Field Test;

5. Revision of Limited Field Test Results;

6. Play Field Test;

7. Revision of Wider Field Test Results; 
8. Feasibility Test;

9. Final Revision of Feasibility Test Results

10. Desimination and Implementation of Final Products

To strengthen the validity of the data found, researchers refer to the use of data validity standards consisting of: credibility, transperability, dependability and comfirmability. While data collection techniques are carried out through 3 (three) stages of activities, namely first; the process of entering the research location (getting in). Second stage; approach to the parties involved in the development of the pemswalinal teamwork model, such as the head of the madrasah, deputy head of madrasah and several teachers, employees and employees who will be friends and informants in this study. The third stage is the stage of data collection (logging the data) by means of observation, in-depth interviews (in-dept interviews); and study documents and records during this research.

The data analysis process is carried out continuously, together with data collection and then continued after the data collection is completed. In analyzing the data of the researchers three stages, namely: data reduction (data reduction), data presentation (data display) and conclusion drawing or conclusion (conclusion drawing / verification) which is commonly known as interactive analysis model.

\section{RESULTS AND DISCUSSION}

A. Teamwork Education Staff at the State Aliyah Madrasah (MAN) 2 Padangsidimpuan Model

There are two forms of teamwork developed in the Madrasah Aliyah Negeri (MAN) 2 Padangsidimpuan model, namely permanent teamwork and temporal teamwork. Permanent teamwork is a teamwork tasked with helping madrasah heads to formulate, implement and evaluate policies determined by the head of the madrasah. While temporal teamwork is teamwork that is responsible for solving certain problems and specific tasks.

Permanent teamwork is self managed teamwork as explained earlier. This teamwork formulates policy planning, implements and evaluates the policy together with fellow members. As for what determines the members of teamwork is the head of the madrasah.

Initially the member of teamwork at the State Aliyah Madrasah (MAN) 2 Padangsidimpuan model was composed of members of the State Aliyah Madrasah 2 Model Padangsidimpuan (MAN) organizational structure, namely; madrasa head, deputy head, madrasa committee, administration and treasurer. These are the members of the teamwork formed by the head of the madrasah before the research is conducted.

After conducting research, based on recommendations foom the Forum Group Discusion (FGD), the members of the education teamwork team experienced development from the previous one. The development of teamwork members is based on the needs and representativeness of the competence of teachers and employees as education personnel. The development can be seen in the following table:
TABle I. Member of Teamwork Before AND AFter Research

\begin{tabular}{|c|c|c|}
\hline No & $\begin{array}{c}\text { Member of } \\
\text { Teamwork Before } \\
\text { Research }\end{array}$ & $\begin{array}{c}\text { Member of Teamwork After } \\
\text { Research }\end{array}$ \\
\hline 1 & Head of Madrasah & Head of Madrasah \\
\hline 2 & $\begin{array}{l}\text { Deputy Field } \\
\text { Curriculum of } \\
\text { Deputy } \\
\text { Curriculum }\end{array}$ & $\begin{array}{l}\text { Deputy Field Curriculum of } \\
\text { Deputy Curriculum }\end{array}$ \\
\hline 3 & $\begin{array}{l}\text { Deputy for } \\
\text { Student Affairs } \\
\text { Deputy for } \\
\text { Student Affairs } \\
\end{array}$ & $\begin{array}{l}\text { Deputy for Student Affairs Deputy } \\
\text { for Student Affairs }\end{array}$ \\
\hline 4 & $\begin{array}{l}\text { Deputy for Public } \\
\text { Relations } \\
\text { Representatives in } \\
\text { Public Relations }\end{array}$ & $\begin{array}{l}\text { Deputy for Public Relations } \\
\text { Representatives in Public Relations }\end{array}$ \\
\hline 5 & $\begin{array}{l}\text { Deputy Head of } \\
\text { Deputy Facilities } \\
\text { and Infrastructure } \\
\text { Head of Facilities } \\
\text { and Infrastructure }\end{array}$ & $\begin{array}{l}\text { Deputy Head of Deputy Facilities } \\
\text { and Infrastructure Head of Facilities } \\
\text { and Infrastructure }\end{array}$ \\
\hline 6 & - & $\begin{array}{l}\text { Chair of team for Improving the } \\
\text { Quality of Teachers and Employees }\end{array}$ \\
\hline 7 & - & $\begin{array}{l}\text { Chair of the Religion Science Study } \\
\text { Program }\end{array}$ \\
\hline 8 & - & $\begin{array}{l}\text { Chair of the Natural Sciences Study } \\
\text { Program }\end{array}$ \\
\hline 9 & - & $\begin{array}{l}\text { Chair of the Social Sciences Study } \\
\text { Program; }\end{array}$ \\
\hline 10 & - & $\begin{array}{l}\text { Chair of the Language Studies } \\
\text { Program }\end{array}$ \\
\hline 11 & - & Head of Administration \\
\hline 12 & - & Treasurer; \\
\hline 13 & - & Librarian \\
\hline 14 & - & Security Officer \\
\hline
\end{tabular}

From the table above it can be seen clearly that there is a development of the number of teamwork staff members from before and after this research. There are several reasons why there is an increase in the number of teamwork, namely:

1. In order to be able to add variety to teamwork competencies so that problems and tasks in the madrasah can be solved;

So that the problems found and resolved can be more detailed and detailed so that they can realize national education goals, the vision and mission of the ministry of religion and the vision and mission of the madrasah

Based on the table above it can be seen that there are additional teamwork members, namely;

1. Field of improving the quality of teachers and employees;

2. Chair of the study program;

3. Chair of the Library;

4. Chief of Security

The reason for including the chairperson for the improvement of the quality of teachers and employees is that he is more aware of the profile of existing teachers and employees and many policies are also related to improving the quality of teachers and employees. While the reason for participating in the chair of the study program is to improve the quality of study programs in the Padangsidimpuan Model 2 Madrasah Aliyah Nergeri (MAN). In addition, based on the results of a study by the Forum Group Discussion, the head of the library and security is considered important to improve the quality of madrasah programs and every madrasah policy is always related to security. 
That is the reason for the addition of the number of members of the Padangsidimpuan Model Madrasah Aliyah Nergeri (MAN) 2 team.

Teamwork of education personnel at the Padangsidimpuan Model 2 Aliyah Nergeri Madrasah (MAN) always holds work meetings every Wednesday. Teamwork members meet not only to solve problems, but also to convey new information to teamwork members to be delivered to all teachers and employees through permanent teamwork members. Because in addition to teamwork members meetings there are also other work meetings, such as general meetings, KKM meetings, homeroom meetings, MGMP meetings and so on.

The head of the madrasah has also prepared meeting rooms and facilities needed for teamwork, such as a comfortable and airconditioned room, soundproofed so that it is not noisy, has a bathroom and toilet, loudspeakers, whiteboards, round chairs and tables.

In addition to the permanent teamwork of educational staff as explained above, the madrasah head also forms teamwork with temporal folds. During the time this research was conducted there were six temporal teamwork that had been formed by the head of the madrasah. The temporal teamwork is as follows:

1. Teamwork in charge of solving student deliquency problems. This teamwork is led by the Deputy Head of Madrasah in the field of student affairs'

2. Teamwork that is tasked to assist the teacher in the problem solving. This teamwork is led by the Head of Teacher and Employee Quality Improvement.

3. Teamwork in charge of accepting new students. This teamwork is led directly by the Madrasah Head.

4. Teamwork is tasked with preparing work programs and budgets before being submitted to permanent teamwork. This teamwork is led directly by the head of the madrasah.

5. Teamwork in charge of succeeding the National Examination and Farewell to Class XII. This teamwork is led by a teacher assigned by the Madrasah Head.

B. Development of a National Teamwork Model of Teaching Staff at Padangsidempuan Madrasah Aliyah Negeri 2 Model

Based on the results of the research that has been carried out, there are two types of teamwork of educational personnel that have been formed by the Head of the State Aliyah Madrasah (MAN) 2 Padangsidimpuan Model, namely the type of permanent teamwork and temporal temwork. Members of the permanent teamwork type which is better known as the self-management or management teamwork model consists of various members who have different competencies in State Aliyah Madrasah 2 Model Padangsidimpuan.

Teamwork is tasked with helping madrasah heads to formulate, implement and conduct policy evaluations. At the beginning before the research was carried out, teamwork that helped the madrasah head did not exist. The head of the madrasah conducted a consultation with only a few members of the organizational structure, namely the deputy head of the madrasa, the madrasah committee, administration and treasurer.

There are several records found when this permanent teamwork was formed. Determination of teamwork members develops according to needs. At the beginning of the meeting the formation of teamwork, members of the teamwork consisted only of the head of the madrasah, the deputy head of the madrasah, the madrasah committee, the administration and the treasurer. After the third meeting there was a proposal from teamwork members to increase the number of teamwork members so that the competencies increased. The increase in the number of teamwork members is due to the need for some more detailed information from the Chair of the Field of Teacher and Employee Quality Improvement. He has teacher data that has been certified and not yet, Data on teachers who teach subjects accordingly or not in accordance with educational background, and data on teacher education levels

In addition, in the teamwork members' meeting also came the idea to include the head of the study program as a member of teamwork. This is because every meeting is often encountered with problems related to the study program. One of the differences between madrasah at the level of ibtidaiyah, tsanawiyah and aliyah is that at the level of madrasah aliyah there are already study programs. Therefore, it needs to be improved and developed. Existing work programs at the State Madrasah Aliyah Negeri (MAN) 2 Padangsidimpuan model are always related to the existing study programs, namely study programs of religious sciences, science, social studies and languages.

While the laboratory chair does not participate in teamwork members. This is because the head of the laboratory is under the Deputy Head of Facilities and Infrastructure Division. Therefore, all laboratory heads are members of teamwork from the Deputy Head of Infrastructure Facilities. So that their competence has been represented in the field of facilities and infrastructure.

The Chairperson of the Library and Security is a member of the teamwork. This has its own considerations, namely in relation to national education goals, the vision and mission of the ministry of religion and the vision and mission of the madrasah. According to the Padangsidimpuan Model Head of Madrasah Aliyah Negeri (MAN) 2, the library is needed in every madrasah policy.

Policies in Madrasah are also related to security. Therefore, the Chairperson of the Security Sector must be involved in a meeting of members of the teamwork. Therefore at the meeting the teamwork members always experience development.

In addition to competency problems there are also five more elements in a teamwork, namely; commitment, shared goals, collaboration, communication and personal interaction. Every time the meeting was held, the head of the madrasah continued to instill values to improve the commitment of the teamwork members.

Whereas the common goal of the members of teamwork was formulated in the vision and mission of the madrasah, namely: The Implementation of Excellent Education and Culture Services to Form Smart and Civilized Indonesian People. To achieve this vision, developed in the form of the following mission:

1. Increase the Availability of Education and Culture Services

2. Expand the Affordability of Education Services

3. Improving the Quality of Educational and Cultural Services

4. Realizing Equality in Getting Education Services

5. Ensuring Certainty / Guaranteed Obtaining Education Services

Cooperation is one element in teamwork. Members of the teamwork of the Madrasah Aliyah Negeri (MAN) 2 education staff in the Padangsidimpuan model always carry out their respective tasks which have been determined by the head of the madrasah. To solve the problems found, it is resolved in a teamwork meeting held every Wednesday. In teamwork the right solution will be discussed.

In teamwork meetings there is an increase in interpersonal communication and interaction. Based on the results of observations made. Communication and interaction between teamwork members will increase along with teamwork meetings. Members are increasingly open to convey the problems they encounter in carrying out their tasks, while other members are increasingly open to expressing opinions as solutions in the problems faced.

If analyzed, the application of the Pemswalinal teamwork model in the State Aliyah Madrasah Model 2 Padangsidimpuan can be concluded in the following table: 
table II. Pemswalinal Teamwork Model State Aliyah MADRASAH 2 MODEL PADANGSIDIMPUAN

\begin{tabular}{|c|c|c|c|}
\hline No & $\begin{array}{ll}\text { Name } & \text { of } \\
\text { Teamwork } & \\
\end{array}$ & $\begin{array}{l}\text { Teamwork } \\
\text { model }\end{array}$ & Explanation \\
\hline 1 & $\begin{array}{l}\text { Temawork which } \\
\text { assisted the } \\
\text { Madrasah Head to } \\
\text { formulate, } \\
\text { implement and } \\
\text { evaluate. }\end{array}$ & $\begin{array}{l}\text { Self- } \\
\text { Management }\end{array}$ & $\begin{array}{l}\text { Teamwork policy } \\
\text { was led directly by } \\
\text { the Madrasah } \\
\text { Head. }\end{array}$ \\
\hline 2 & $\begin{array}{l}\text { Teamwork in } \\
\text { charge of solving } \\
\text { student } \\
\text { delinquency } \\
\text { problems. }\end{array}$ & $\begin{array}{l}\text { Problem- } \\
\text { solving }\end{array}$ & $\begin{array}{l}\text { The Teamwork } \\
\text { Problem Solver is } \\
\text { led by the Deputy } \\
\text { Head of Madrasah } \\
\text { in the student } \\
\text { affairs field. }\end{array}$ \\
\hline 3 & $\begin{array}{l}\text { Teamwork that is } \\
\text { tasked to assist } \\
\text { the teacher in } \\
\text { solving the } \\
\text { problem. }\end{array}$ & $\begin{array}{l}\text { Cross- } \\
\text { Functional }\end{array}$ & $\begin{array}{l}\text { Teamwork is led } \\
\text { by the Head of } \\
\text { the Teacher and } \\
\text { Employee } \\
\text { Quality } \\
\text { Improvement } \\
\text { Division. }\end{array}$ \\
\hline 4 & $\begin{array}{lr}\begin{array}{l}\text { Teamwork } \\
\text { charge }\end{array} & \text { in } \\
\text { accepting } & \text { of } \\
\text { students. } & \\
\end{array}$ & $\begin{array}{l}\text { Cross- } \\
\text { functional }\end{array}$ & $\begin{array}{l}\text { This teamwork is } \\
\text { led directly by } \\
\text { the Madrasah } \\
\text { Head. }\end{array}$ \\
\hline 5 & $\begin{array}{l}\text { Teamwork that is } \\
\text { tasked with } \\
\text { preparing the } \\
\text { work program } \\
\text { and the budget is }\end{array}$ & $\begin{array}{l}\text { Cross- } \\
\text { functional }\end{array}$ & $\begin{array}{l}\text { directly led by } \\
\text { the head of the } \\
\text { madrasah. }\end{array}$ \\
\hline 6 & $\begin{array}{l}\text { Teamwork in } \\
\text { charge } \\
\text { succeeding the } \\
\text { National } \\
\text { Examination and } \\
\text { Farewell to Class } \\
\text { XII. }\end{array}$ & $\begin{array}{l}\text { Cross- } \\
\text { functional }\end{array}$ & $\begin{array}{l}\text { This teamwork is } \\
\text { led by a teacher } \\
\text { assigned by the } \\
\text { Madrasah Head. }\end{array}$ \\
\hline 7 & $\begin{array}{l}\text { Teamwork in } \\
\text { charge of carrying } \\
\text { out physical } \\
\text { development, such } \\
\text { as the construction } \\
\text { of classrooms. }\end{array}$ & $\begin{array}{l}\text { Cross- } \\
\text { functional }\end{array}$ & $\begin{array}{l}\text { This teamwork is } \\
\text { led by a teacher } \\
\text { who is assigned } \\
\text { directly by the } \\
\text { Head of the } \\
\text { Madrasah }\end{array}$ \\
\hline
\end{tabular}

C.Effectiveness of the Pemwalinal Teamwork Model on the Management of Education Personnel of Madrasah Aliyah Negeri 2 Padangsidempuan Model

Based on the results of the research conducted, there were several influences of the Pemswalinal Teamwork on the Management of Education Staff at State Aliyah Madrasah 2 Model Padangsidimpuan. These influences are as follows:

1. With the teamwork of education staff, the head of the madrasah is very helpful in carrying out the tasks. Teamwork education personnel assist madrasah heads to formulate, implement and evaluate policies. Teamwork also helps madrasah heads to solve problems in madrasas, such as solving problems of student delinquency, problems faced by teachers and employees.

2. With the teamwork the problems in the madrasah can be solved together. Teamwork works together so that they can solve problems in an appropriate and timely manner. For example, the problem faced by the teacher when carrying out the task, then teamwork will examine what problems faced by the teacher and how to solve them. The teacher does not work alone, but he is assisted by another teacher's friend. Likewise with the application of discipline, the security sector will be involved so that discipline can be applied.

3. With teamwork, teamwork will be established. Thus, all parties will feel involved in a policy. This will lead to a sense of responsibility for the results of decisions with team members.

\section{CONCLUSION}

Based on the results of the research and discussion described above there are several conclusions that can be taken, namely:

1. There are two types of teamwork of education personnel in the State Aliyah Madrasah 2 Padangsidimpuan model, namely the type of permanent teamwork or better known as selfmanagement and teamwork management. This type is responsible for assisting madrasah heads to formulate, implement and evaluate the policies of the madrasah head. Members of this teamwork consist of several teachers and employees who have several competencies as previously explained. The second type of teamwork is the temporal type of teamwork of educational personnel to solve certain problems and carry out certain tasks. During the study there were six teamwork that had been formed by the head of the madrasah, namely: Teamwork is tasked with the problem solving of student delinquency, Teamwork is tasked to assist the teacher in the problem solving. Teamwork that is responsible for accepting new students. Teamwork is tasked with preparing work programs and budgets, Teamwork that is tasked with succeeding the National Examination and Farewell to Class XII.

2. The pemswalinal teamwork model is applied in the State Aliyah Madrasah 2 Padangsidimpuan Model. Problem solving work models are applied to teamwork in charge of solving problems of student delinquency and problems faced by teachers in carrying out tasks. Whereas the self-managed teamwork model is tasked with helping madrasah heads to formulate, implement, and evaluate policies. This teamwork is more permanent and is led directly by the head of the madrasah. The cross-functional teamwork model is tasked with carrying out certain tasks, such as the success of the National Examination, acceptance of new students, madrasah activity planning and budgeting and the implementation of certain projects to build madrasas.

3. Teamwork of education personnel in the State Aliyah Madrasah 2 Model is very influential on the management of education personnel. There are a number of influences, namely: 1) With the teamwork of educational staff, the head of the madrasah is very helpful in carrying out the tasks. 2) With teamwork the problems in the madrasah can be solved together. 3) With teamwork, teamwork will be established. 4) With teamwork will produce good performance.

\section{REFERENCES}

[1] Newstorm, John W., Organizational Behavior: Human Behavior at work, Singapore: Mc Graw Hill, 2007.

[2] Slocum and Hellriegel, Principles of Organizational Behavior, China: South-Western Cengage Learning, 2009, Ed. 12

[3] Slocum and Hellriegel, Principles of Organizational Behavior, China: South-Western Cengage Learning, 2009, Ed. 12

[4] Ministry of National Education, School-Based Quality Improvement Management, Jakarta: Ministry of National Education, book 1, 2004 
[5] J.C.Maywell, Effective Cooperation Law, Batam: Interaction, 2002.

[6] R.Arends. Learning to Teach., Yogyakarta, Learning Library, 2008.

[7] Slocum and Hellriegel, Principles of Organizational Behavior, China: South-Western Cengage Learning, 2009, Ed. 12

[8] Moorhead and Griffin, Managing People and Organizations; Organizational Behavior, Delhi: Virender Kumar Arya, 2001.

[10] Slocum and Hellriegel, Principles of Organizational Behavior, China: South-Western Cengage Learning, 2009, Ed. 12

[11] Slocum and Hellriegel, Principles of Organizational Behavior, China: South-Western Cengage Learning, 2009, Ed. 12

[12] Moorhead and Griffin, Managing People and Organizations; Organizational Behavior, Delhi: Virender Kumar Arya, 2001.

[13] Burhan, Bungin, Metodologi Penelitian Kualitatif, Jakarta: Raja Grafindo Persada, 2007 